\title{
First Simple and Easy Process of Thermal Degrading Municipal Waste Plastics into Fuel Resource
}

\author{
Moinuddin Sarker*, Mohammad Mamunor Rashid \\ Natural State Research, Inc., Department of Research and Development, 37 Brown House Road. Stamford, CT \\ 06902, USA Phone: 1-203-406-0675, Fax: 1-203-406-9852
}

\begin{abstract}
Liquid fuel i.e. hydrocarbon fuel obtained from four different types of waste plastics low and high density polyethylene (LDPE and HDPE), polypropylene (PP) and polystyrene (PS) were carried out in a reactor stainless steel system. Each of the plastics has different chemical and physical properties so the experiments were carried out individually for each of them. Simple thermal degradation was used to melt the plastics at temperature ranging from 120 to $400{ }^{\circ} \mathrm{C}$. Vapor condensation form the melted plastics produced the liquid hydrocarbon product. Similar standards were followed for each of the plastics during the production process. The effect of reaction on quality and yield of the product were investigated. The liquid product formed was analyzed using gas chromatography (GC) with mass spectrometer (MS) (Clarus-500) and FT-IR spectrometer spectrum 100 (Perkin-Elmer). The chemical properties of the liquid product had varied from each plastic. Each of the liquid products contained low sulfur but each of them varied from each other. The waste plastics can also be randomly mixed with each other prior to the liquid production process. The results of mixed plastics production process indicates higher yield percentage than when they are done separately.
\end{abstract}

Keywords: waste plastic, fuel, ldpe, hdpe, pp, ps, hydrocarbon, liquefaction, condensation, thermal

\section{Introduction}

Plastics are "one of the greatest innovations of the millennium" and have certainly proved their reputation to be true. There are a numerous ways that plastic is and will be used in the years to come. Waste plastics contribute to great environmental and social problems due to the loss of natural resources, environmental pollution, depletion of landfill space on the one hand and demands of environmentally-oriented society on the other hand. The fact that plastic is lightweight, doesn't rust or rot, low cost, reusable and conserves natural resources is the reason for which plastic has gained this much popularity. Continuous innovation explains that plastics production has increased by an average of almost $10 \%$ every year on a global basis since 1950. The total global production of plastics has grown from around 1.3 million tonnes (MT) in 1950 to 245 MT in 2006. Plastics continue to be a global success story with Europe and Switzerland major manufacturing region, producing about $25 \%$ of the total estimated worldwide plastics production of 245 million tonnes during 2006. An analysis of plastics consumption on a per capita basis shows that this has now grown to over $100 \mathrm{~kg} / \mathrm{y}$ in North America and Western Europe, with the potential to grow to up to $130 \mathrm{~kg} / \mathrm{y}$ per capita by 2010 [1]. The amount of waste plastics requiring landfill disposal has been rapidly increasing in recent years. Currently around $20 \%$ of the volume and $8 \%$ of the weight of all municipal solid waste in the US is made up of waste plastics [2]. Of the approximately 80 billion pounds of plastics currently produced in the United States, most eventually ends up in landfills, with only $2-3 \%$ recycled [3]. The huge population increase coupled with the improved living conditions of the people led to a dramatical increase of the consumption of plastics worldwide. The chief usages of polymeric materials are packaging, household and domestic products, electrical and electronic goods and also in building, construction and automotive industries. It has been estimated that almost 170 million tones of plastics were produced worldwide during the year 2003. Current statistics for Western Europe estimate the annual total consumption of plastic products at 48.8 million tons for 2003 and generating approximately 15 million tons of waste plastics throughout Europe [4]. In 2006, the United States generated about 14 million tons of plastics in the form of municipal solid waste (MSW) as containers and packaging, over 6 million tons as nondurable goods, and almost 9 million tons as durable goods. Fig. 1 showed also plastic production in million ton per year in USA. The total amount of plastics in MSW-almost 30 million tons - represented 11.7\% of total MSWgeneration in 2006 [5]. In contrast to paper and garbage wastes most plastics are not readily biodegradable and will remain in the landfill for indeterminate periods. The ever increasing costs of landfill disposal coupled with a significant public resistance to the creation of new waste landfill has led to increased efforts toward finding economically feasible and environmentally acceptable means of recycling these materials. Disposal of these waste plastics by direct incineration would lead to increased 
greenhouse gas emissions, primarily carbon dioxide $\left(\mathrm{CO}_{2}\right)$ and particulate pollutants. At present, it is almost impossible to dispose of waste plastics by landfill due to the law, high costs, and higher ecological consciousness of people. However, there are also some technological and economic constrains that limit the full and efficient recycling of plastic wastes into useful products, e.g. contaminated waste plastics can be only partly recycled into new products and reuse of packaging containers is limited by the collection systems. Mechanical recycling that probably is the best way of reclaiming plastics refers to the processes which involve sorting, shredding or melting and re-granulation. It may be applied only for the same type and clean plastics. Up to the present moment, energy recovery by incineration has seemed to be the second attractive option for waste plastics utilization that takes advantage of the high energy content of plastics and reducing the garbage volumes by over $90 \%$. However, sometimes, it was questioned due to the lack of raw materials recovery, the low thermodynamic efficiency, the possible emission of toxic gaseous compounds and necessity of purification of flue gases that is difficult and expensive. Even though, current technologies would conform the emission requirements, incineration arouses almost always public resistance and objections $[6,7,8]$. Some research group also worked with plastic conversion into fuel catalytic process [9-20], thermal degradation process [2133] and pyrolysis process [34-38]. Natural State Research, Inc. (NSR) invented a unique process which easy and simple way to converted most of waste plastics into fuel resources and investigated that the reaction of experiment continues randomly without any catalyst or chemical substances. Experiment output calculated and found that maximum percentage of liquid products collected, rest of product are the gases and residues as well.

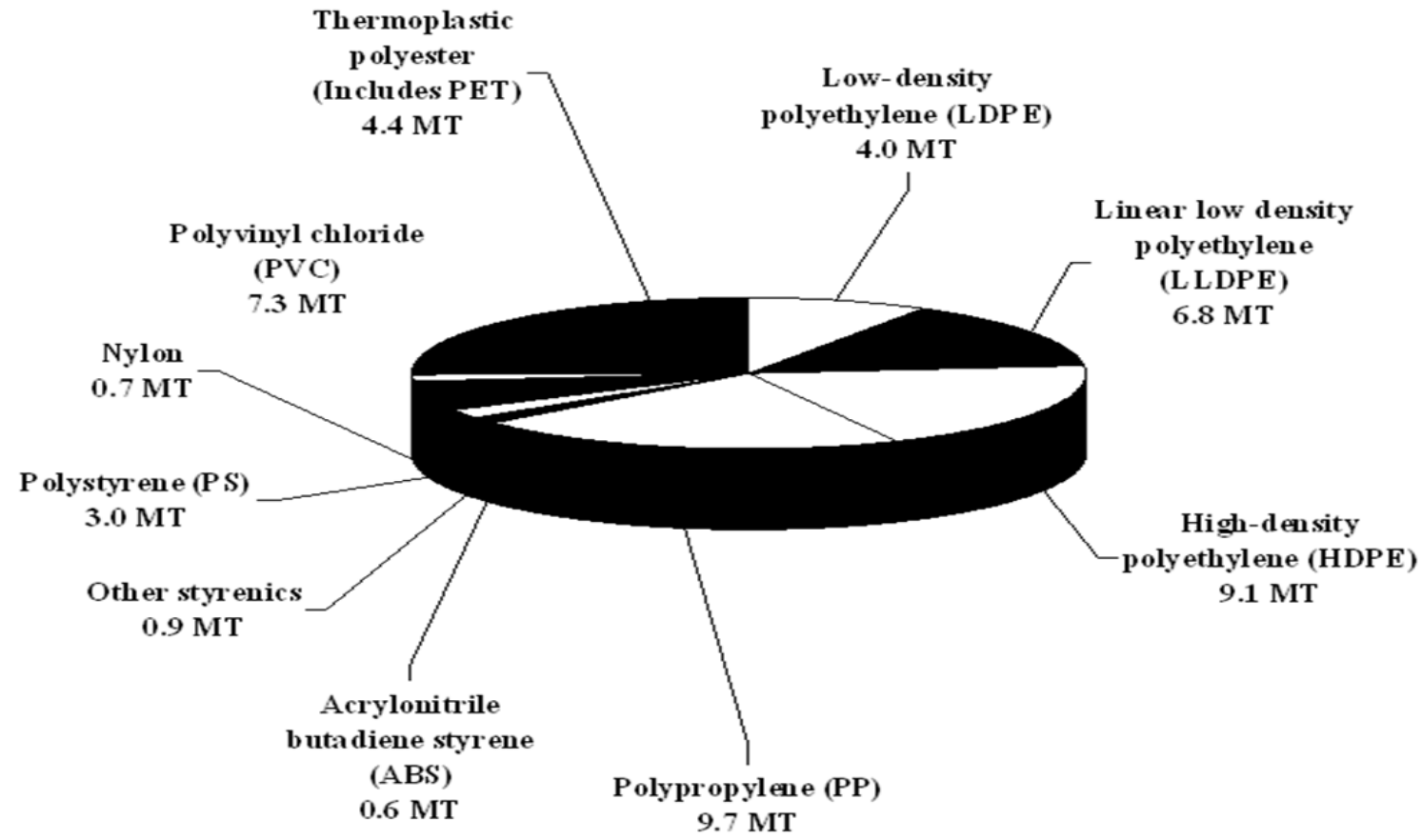

Figure 1: Individual Plastic Production in Million Ton (MT) per Year

\section{Experiment Section Description}

\subsection{Pre Analysis of Raw Materials}

Different types of waste plastics properties are elaborated such as each polymer density, melting point, tensile strength and water absorption etc. Related data are given below (See Table 1).

Table 1: Raw Plastic Properties

\begin{tabular}{|c|c|c|c|c|}
\hline Plastic Name & Density g/cm3 & Melting Point ${ }^{\circ} \mathrm{C}$ & Tensile Strength psi & $\begin{array}{c}\text { Water Absorption } \\
\text { Rate } \%\end{array}$ \\
\hline HDPE-2 & 0.95 & 130 & 4550 & 0.01 \\
\hline LDPE-4 & 0.92 & 120 & 1700 & 0.01 \\
\hline PP-5 & 0.94 & 160 & 5000 & $0.01-0.03$ \\
\hline PS-6 & 1.05 & 240 & $6671-8702$ & $0.03-0.1$ \\
\hline
\end{tabular}




\section{Fourier Transform Infra-red Spectroscopy (FT-IR) Analysis:}

Perkin Elmer, FT-IR (Fourier Transform Infra-red Spectroscopy) Spectrum-100, employed to analysis purposes. FTIR Program set up are elaborated, before sample run, Visible ray range were $4000-400 \mathrm{~cm}^{-1}$, used $\mathrm{NaCl}$ cell is $0.05 \mathrm{~mm}$, Taken Scan Number is 32 and Resolution number is 4 .

HDPE waste plastics were analyzed by FT-IR (Spectrum 100). Obtained functional groups are described as well. In wave number $2895 \mathrm{~cm}^{-1}$ functional group is $\mathrm{C}_{-} \mathrm{CH}_{3}$, wave number $2847.92 \mathrm{~cm}^{-1}$ functional group is Non-Conjugated, wave number $1472.55 \mathrm{~cm}^{-1}, 1462.30 \mathrm{~cm}^{-1}$, functional group is $\mathrm{CH}_{3}$ and $\mathrm{CH}_{2}$, and finally on wave number $730.18 \mathrm{~cm}^{-1}$ and 718.74 functional compound is $-\mathrm{CH}=\mathrm{CH}$ - (cis) etc.

LDPE waste plastics were analyzed by FT-IR. Obtained functional groups are described as well. In wave number $2916.29 \mathrm{~cm}^{-1}$ functional group is $\mathrm{CH}_{2}$, also in wave number $2848.45 \mathrm{~cm}^{-1}$ functional group is $\mathrm{CH}_{2}$, as well as wave number $1740.93 \mathrm{~cm}^{-1}$ functional group is Non-Conjugated ,wave number $1462.77 \mathrm{~cm}^{-1}$, and $1462.77 \mathrm{~cm}^{-1}$ functional group is $\mathrm{CH}_{3}$ and finally on wave number $1020.04 \mathrm{~cm}^{-1}$ and 718.74 functional compound is Acetates and $-\mathrm{CH}=\mathrm{CH}-$ (cis) etc.

PP waste plastics were analyzed by FT-IR. Obtained functional groups are described as well. In wave number $2950.26 \mathrm{~cm}^{-1}$ functional group is $\mathrm{C}_{-} \mathrm{CH}_{3}$, also in wave number $2916.91 \mathrm{~cm}^{-1}$ functional group is $\mathrm{CH}_{2}$, as well as wave number $2837.40 \mathrm{~cm}^{-1}$ functional group is $\mathrm{C}_{-} \mathrm{CH}_{3}$, wave number $1452.83 \mathrm{~cm}^{-1}$ and $1375.78 \mathrm{~cm}^{-1}$ functional group is $\mathrm{CH}_{3}$ and $\mathrm{CH}_{3}$. Ultimately on wave number $997.41 \mathrm{~cm}^{-1}$ and 972.74 functional compounds is Secondary Cyclic Alcohol etc.

PS waste plastics were also analyzed by FT-IR. Obtained functional groups are described as well. In PS-6 analysis noticeable more functional compounds are appeared. In wave number $3082.06 \mathrm{~cm}^{-1}$ functional group is $\mathrm{H}$ Bonded $\mathrm{NH}$, wave number $3059.67 \mathrm{~cm}^{-1}$ functional group is $-\mathrm{C}=\mathrm{CH}$, wave number 2921.66 functional group is $\mathrm{CH}_{2}$, wave number $2849.89 \mathrm{~cm}^{-1}$ functional group is $\mathrm{C}_{-} \mathrm{CH}_{3}$, wave number $1744.35 \mathrm{~cm}^{-1}$, and $1600.85 \mathrm{~cm}^{-1}$ functional group is Conjugated, wave number $1461.62 \mathrm{~cm}^{-1}$ and 1371.15 functional group is $\mathrm{CH}_{3}$ and wave number $1027.71 \mathrm{~cm}^{-1}$ functional group is Acetates, wave number $963.94 \mathrm{~cm}^{-1}$ functional group is $-\mathrm{CH}=\mathrm{CH}-\left(\right.$ Trans) and ultimately on wave number $905.99 \mathrm{~cm}^{-1}$ and 748.32 functional compound is $-\mathrm{CH}=\mathrm{CH}_{2}$ and $-\mathrm{CH}=\mathrm{CH}-(\mathrm{cis})$ respectively.

\subsection{Process Description}

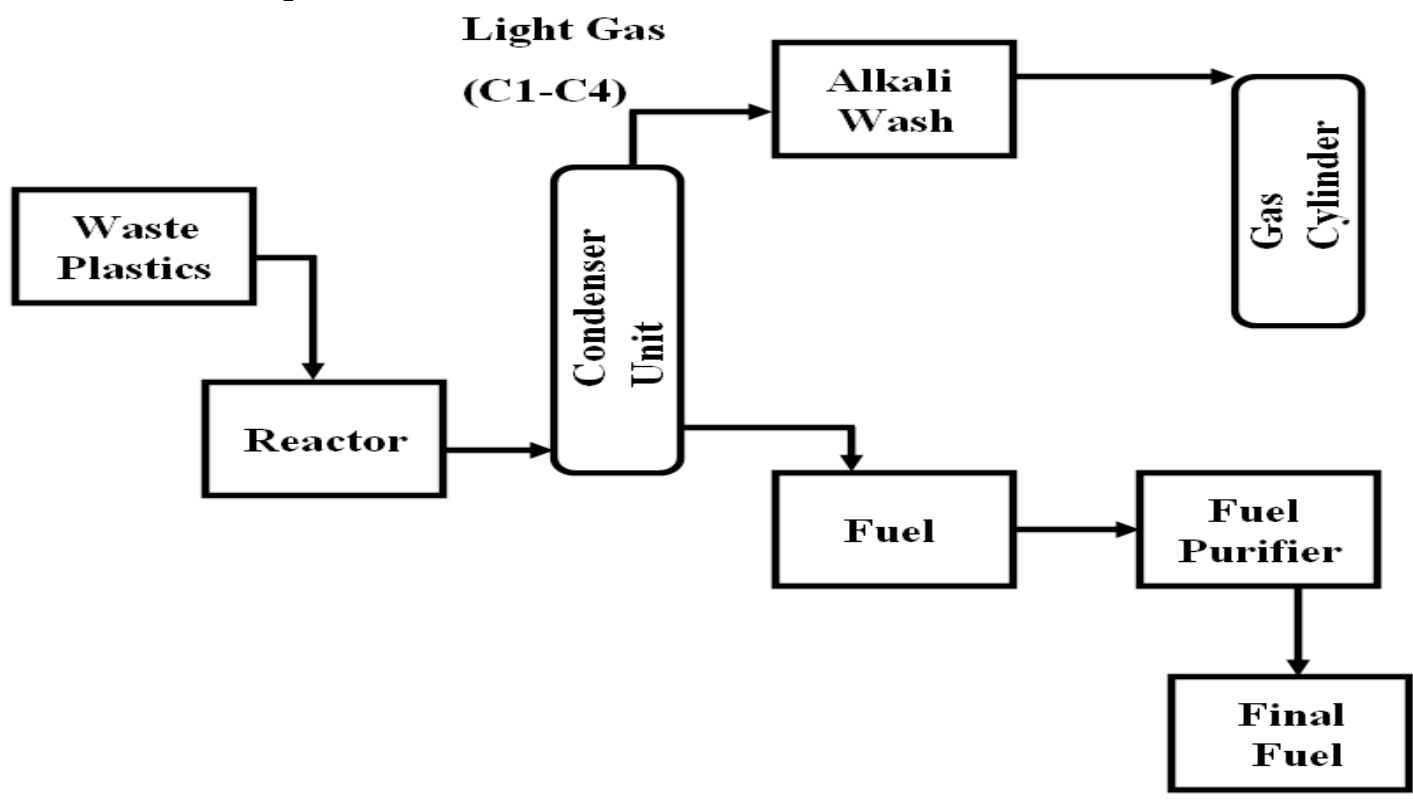

Figure 2: Waste Plastic into Fuel Production Process

The process has been conducted in small scales with individual plastics in laboratory, on various waste plastics types; High-density polyethylene (HDPE, code 2), low-density polyethylene (LDPE, code 4), polypropylene (PP, code 5) and polystyrene (PS, code 6). These plastic types were investigated singly. For small-scale laboratory process the weight of input waste plastics ranges from 400 grams to $3 \mathrm{~kg}$ (see fig.2). These waste plastics are collected, optionally sorted, cleaned of contaminants, and shredded into small pieces (Size 2.5 square $\mathrm{mm}$ ) prior to the thermal liquefaction process. The process of converting the waste plastic to alternative energy begins with heating the solid plastic without the presence of cracking catalyst to form liquid slurry (thermal liquefaction in the range of $120-420^{\circ} \mathrm{C}$ ), condensing the vapor with standard condensing column 
to form liquid hydrocarbon fuel termed "NSR fuel". Preliminary tests on the produced NSR fuel have shown that it is a mixture of various hydrocarbons having a range of carbon chain lengths for HDPE plastics to fuel $\mathrm{C}_{3}$ to $\mathrm{C}_{28}$, LDPE plastics to fuel from $\mathrm{C}_{3}$ to $\mathrm{C}_{28}$ PP-5 plastics to fuel $\mathrm{C}_{3}$ to $\mathrm{C}_{25}$ and PS-6 plastics to fuel from $\mathrm{C}_{6}$ to $\mathrm{C}_{18}$. The produced fuel density individually elaborated such as HDPE-2 fuel density is $0.782 \mathrm{~g} / \mathrm{ml}$, LDPE-4 fuel density is $0.771 \mathrm{~g} / \mathrm{ml}, \mathrm{PP}-5$ fuel density is 0.759 and PS-6 fuel density is 0.916 (see table 3). In equivalent to obtaining the liquid hydrocarbon fuel we also received light gaseous hydrocarbon compounds $\left(\mathrm{C}_{1}-\mathrm{C}_{4}\right)$ which resembles natural gas and table is showing individual plastic to fuel production yield \%, light gas $\%$ and solid residue \% ( See table2). Every individual waste plastic to fuel production experiment take time 5-6 hours and also input electricity for every individual experiment $14-15 \mathrm{kWh}$ for 1 gallon production. Light gas wash by alkali wash and light gas analysis under consideration.

Table2: Individual Waste Plastic to Fuel Production Yield Percentage

\begin{tabular}{|c|c|c|c|}
\hline Name of Waste Plastic & Fuel Production Yield \% & Light Gas $\left(\mathrm{C}_{1}-\mathrm{C}_{4}\right) \%$ & Solid Residue \% \\
\hline HDPE-2 & 89.354 & 5.345 & 5.299 \\
\hline LDPE-4 & 87.972 & 5.806 & 6.221 \\
\hline PP-5 & 91.981 & 2.073 & 5.944 \\
\hline PS-6 & 85.331 & 6.995 & 7.674 \\
\hline
\end{tabular}

Table 3: Individual Waste Plastic to Fuel Physical Properties

\begin{tabular}{|c|c|c|c|c|}
\hline $\begin{array}{c}\text { Name of Waste } \\
\text { Plastic Fuel }\end{array}$ & $\begin{array}{c}\text { Fuel Density } \\
\mathrm{g} / \mathrm{ml}\end{array}$ & $\begin{array}{c}\text { Specific } \\
\text { Gravity }\end{array}$ & Fuel Color & Fuel Appearance \\
\hline HDPE-2 & 0.782 & 0.7812 & Yellow, light transparent & $\begin{array}{c}\text { Wax and ash } \\
\text { contain present }\end{array}$ \\
\hline LDPE-4 & 0.771 & 0.7702 & Yellow, no transparent & $\begin{array}{c}\text { Cloudy, wax and } \\
\text { ash contain present }\end{array}$ \\
\hline PP-5 & 0.759 & 0.7582 & $\begin{array}{c}\text { Light brown, light } \\
\text { transparent }\end{array}$ & $\begin{array}{c}\text { Wax and ash } \\
\text { contain present }\end{array}$ \\
\hline PS-6 & 0.916 & 0.9150 & Light yellow, no transparent & $\begin{array}{c}\text { Cloudy, wax and } \\
\text { ash contain present }\end{array}$ \\
\hline
\end{tabular}

\subsection{GC/MS Analysis of Each Individual Fuel}

\section{Fuel Analysis Result and Discussion}

Perkin Elmer, GCMS Clarus-500 (Gas Chromatography and Mass Spectroscopy) was used to analysis purposes. GC Method programs set up are point out here, that's elaborated below. Initial temperature was $40^{\circ} \mathrm{C}$ for 1 minute. Ramping Rate: $10^{\circ} \mathrm{C} /$ minute, Highest Temperature: $325^{\circ} \mathrm{C}$, Hold at $325^{\circ} \mathrm{C}$ for 15 minute, Run Time: 44.50 minute, Sample Inject Volume: $0.5 \mu \mathrm{L}$, Carrier Gas: Helium (He).

In MS Method Set up Solvent delay was 1 Minute. Mass detection: start at $35 \mathrm{~m} / \mathrm{z}$, End at $528 \mathrm{~m} / \mathrm{z}$. Ionization Mode: EI+, Data: Centroid. Scan Time: $0.25 \mathrm{~s}$ and Inter Scan delay: 0.15s.Perkin Elmer GC Capillary Column Used. Elite-5MS, Length, 30 meter, Inner Diameter 0.25, 0.5umdf, Maximum Program Temperature at $350{ }^{\circ} \mathrm{C}$ and Minimum Bleed at $330^{\circ} \mathrm{C}$.

After all program set up HDPE-2 fuel analyzed by GCMS. From GCMS analysis in versus of retention time following types of hydrocarbon compounds are appeared. Depends on different retention time different compounds are appeared, such as at retention time $(\min ) 1.56$ obtained compound Propane $\left(\mathrm{C}_{3} \mathrm{H}_{8}\right)$, at retention time 1.66 compound is Butene, $(\mathrm{E})-\left(\mathrm{C}_{4} \mathrm{H}_{8}\right)$, at retention time 1.96 and 2.00 found compound are Butane $\left(\mathrm{C}_{4} \mathrm{H}_{10}\right)$ and Pentane $\left(\mathrm{C}_{5} \mathrm{H}_{12}\right)$. Retention time versus compound determination focused on higher the retention time represents the bulky or bigger the compound size. Suppose in the middle of the analysis chart appearing that at retention time 8.67, 9.65, 9.80 the compounds are Cyclohexane Propyl-, 1-Decene and Decane respectively. In the analysis high number of retention time are found such as 21.71, 22.64, 22.71, 23.64, 23.71,27.98,28.09,30.24,30.38 and their compounds are Eicosane $\left(\mathrm{C}_{20} \mathrm{H}_{42}\right)$, 5-Eicosane, $\left(\mathrm{C}_{20} \mathrm{H}_{42}\right)$,Eicosane $\left(\mathrm{C}_{20} \mathrm{H}_{42}\right)$ and Heneicosene $(\mathrm{c}, \mathrm{t})\left(\mathrm{C}_{21} \mathrm{H}_{44}\right), 1$-Decosene $\left(\mathrm{C}_{22} \mathrm{H}_{44}\right),\left(\mathrm{C}_{24} \mathrm{H}_{44}\right), 1$-Decosene $\left(\left(\mathrm{C}_{22} \mathrm{H}_{44}\right)\right.$ and Octacosane $\left(\mathrm{C}_{28} \mathrm{H}_{58}\right)$ (See fig.3). 


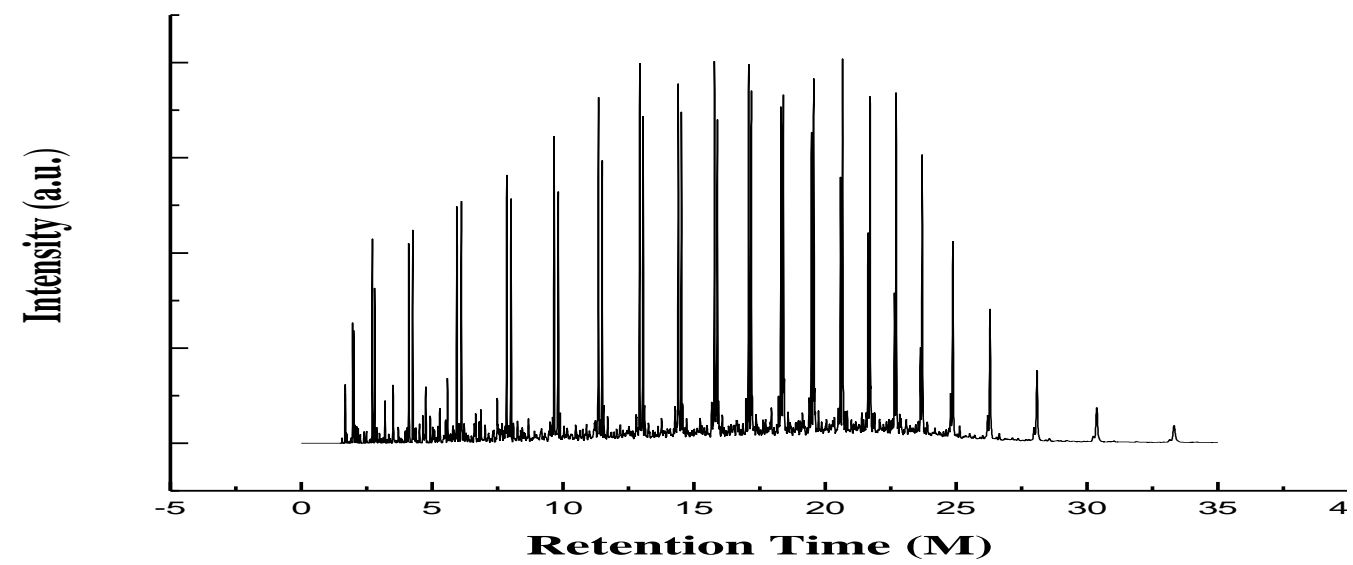

Figure 3: Gas Chromatography and Mass Spectrometer Chromatogram of HDPE to Fuel

GC/MS analysis of LDPE-4 upon retention time following compounds are found initially such as at retention time 1.55, compound is Cyclopropane $\left(\mathrm{C}_{3} \mathrm{H}_{6}\right)$, retention time 1.68 , compound is butane $\left(\mathrm{C}_{3} \mathrm{H}_{10}\right)$, retention time 1.96, compound is 2-Pentene $(\mathrm{E})\left(\mathrm{C}_{5} \mathrm{H}_{10}\right)$, retention time 1.99 , compound is $\left(\mathrm{C}_{5} \mathrm{H}_{12}\right)$, retention time 2.70, compound is 3-Hexene, $(\mathrm{Z})\left(\mathrm{C}_{6} \mathrm{H}_{12}\right)$, retention time 3.18 compound is Cyclopropane, methyl- $\left(\mathrm{C}_{3} \mathrm{H}_{6}\right)$. In the middle of the analysis report at retention time 11.35 compound is 1-Undecene $\left(\mathrm{C}_{11} \mathrm{H}_{22}\right)$, retention time 11.44 compound is Undecane $\left(\mathrm{C}_{11} \mathrm{H}_{24}\right)$ etc. At the end of the analysis report at higher retention time bulky or large compound are derived, such as at retention time 20.68 compound is Eicosane $\left(\mathrm{C}_{20} \mathrm{H}_{42}\right)$, retention time 21.41 compound is 1-Nonadecanol $\left(\mathrm{C}_{19} \mathrm{H}_{40} \mathrm{O}\right)$, retention time 23.64 compound is 1-Docosene $\left(\mathrm{C}_{22} \mathrm{H}_{44}\right)$, retention time 28.09 compound is Tetracosane $\left(\mathrm{C}_{24} \mathrm{H}_{50}\right)$ and finally at retention time 33.21 compound is Octacosane $\left(\mathrm{C}_{28} \mathrm{H}_{58}\right)$ (see fig.4).

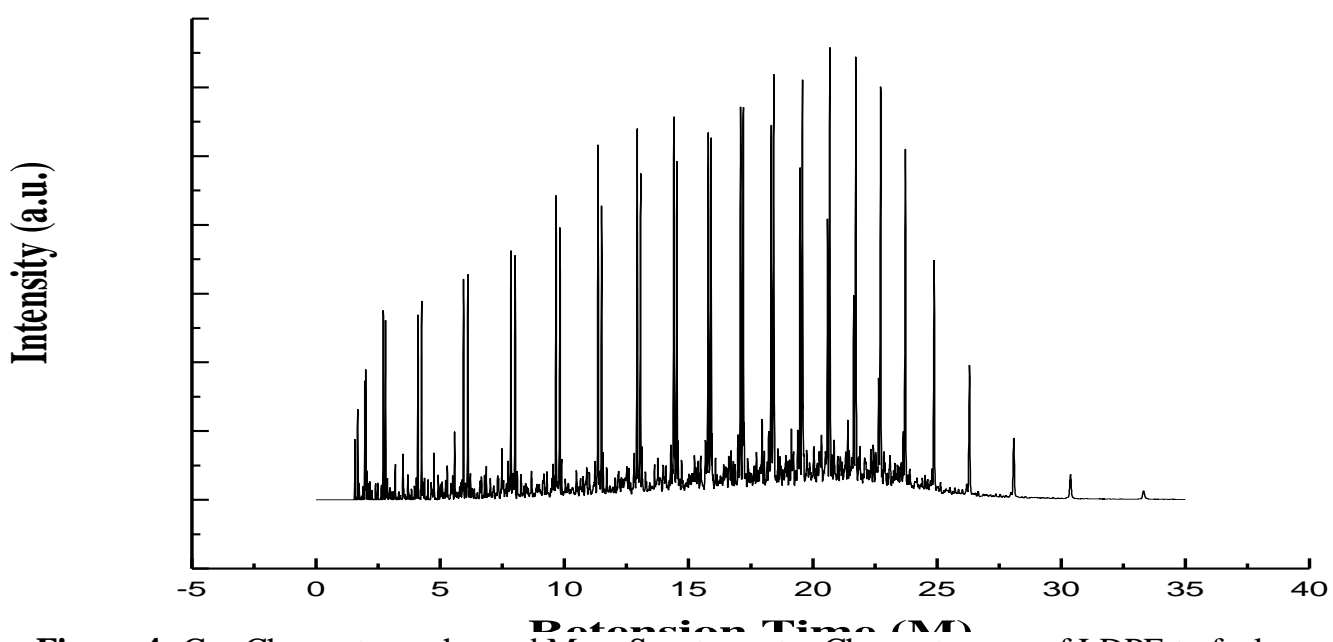

Figure 4: Gas Chromatography and Mass Spectrometer Chromatogram of LDPE to fuel

GC/MS analysis of PP-5 upon retention time following compounds are found initially such as at retention time 1.55, compound is Cyclopropane $\left(\mathrm{C}_{3} \mathrm{H}_{6}\right)$, retention time 1.66, compound is 1-Propene,2-methyl $\left(\mathrm{C}_{4} \mathrm{H}_{8}\right)$, retention time 2.48, compound is Pentane, 2-Methyl- $\left(\mathrm{C}_{6} \mathrm{H}_{14}\right)$, retention time 2.69, compound is 2Hexene $(\mathrm{Z}),\left(\mathrm{C}_{6} \mathrm{H}_{12}\right)$, retention time 3.40, compound is 1-Pentene,2,4-dimethyl- $\left(\mathrm{C}_{7} \mathrm{H}_{14}\right)$, retention time 4.28 compound is 1,3-Pentadiene,2,4-dimethy- $\left(\mathrm{C}_{7} \mathrm{H}_{12}\right)$.Chronologically in the analysis report at retention time 5.28 compound is 3-Heptene,4-Methyl- $\left(\mathrm{C}_{8} \mathrm{H}_{16}\right)$, retention time 6.01 compound is 4-Methyl-1,3-heptadine $(\mathrm{c}, \mathrm{t})$ $\left(\mathrm{C}_{8} \mathrm{H}_{14}\right)$ etc. At the end of the analysis report noticeable that at higher retention time bulky or large compound are derived, such as at retention time 16.33 compound is Cyclopropanol,1-(3,7-dimethyl 1-Octenyl)- $\left(\mathrm{C}_{13} \mathrm{H}_{24} \mathrm{O}\right)$, retention time 19.67 compound is 11,13-Dimethyl-12-Tetradecene-1-ol acetate $\left(\mathrm{C}_{18} \mathrm{H}_{34} \mathrm{O}_{2}\right)$, retention time 22.89 compound is Oxirane,Tetradecyl- $\left(\mathrm{C}_{16} \mathrm{H}_{32} \mathrm{O}\right)$, retention time 25.72 compound is Cyclotetradecane , 1,7,11- 
trimethyl-4-(1-methylethyl)- $\left(\mathrm{C}_{20} \mathrm{H}_{40}\right)$ and finally at retention time 28.95 compound is Dodecane,1-cyclopentyl4(3-cyclopentyl propyl)- $\left(\mathrm{C}_{25} \mathrm{H}_{48}\right)$ (see fig.5).

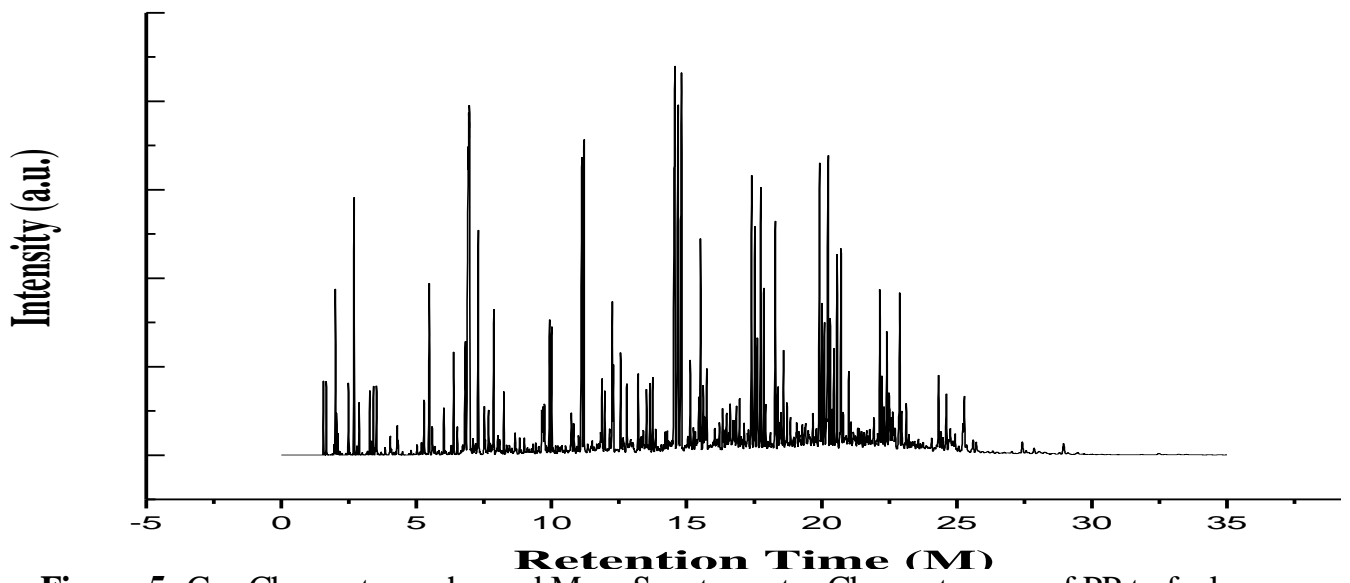

Figure 5: Gas Chromatography and Mass Spectrometer Chromatogram of PP to fuel

GC/MS analysis of PS-6 upon retention time following compounds are found initially such as at retention time 3.65, compound is 1,5-Hexadiyne $\left(\mathrm{C}_{6} \mathrm{H}_{6}\right)$, retention time 5.54, compound is Toluene $\left(\mathrm{C}_{7} \mathrm{H}_{8}\right)$, retention time 7.38, compound is p-Xylene $\left(\mathrm{C}_{8} \mathrm{H}_{10}\right)$, retention time 8.51, compound is Benzene,(1-methylethyl)$\left(\mathrm{C}_{9} \mathrm{H}_{12}\right)$, retention time 9.05 , compound is Benzene,Propyl- $\left(\mathrm{C}_{7} \mathrm{H}_{12}\right)$, retention time 9.20 , compound is Benzaldehyde $\left(\mathrm{C}_{7} \mathrm{H}_{6} \mathrm{O}\right)$, retention time 10.35 compound is Benzene,2-Propenyl- $\left(\mathrm{C}_{9} \mathrm{H}_{10}\right)$.Chronologically in the analysis report at retention time 11.00, compound is Acetophenone $\left(\mathrm{C}_{8} \mathrm{H}_{8} \mathrm{O}\right)$, retention time 17.22 compound is Benzene,1,1-,time bulky or large compound are derived, such as at retention time 17.35, compound is 1,1Biphenyl,4-methyl- $\left(\mathrm{C}_{13} \mathrm{H}_{12}\right)$, retention time 18.03 compound is Benzene,1,1-(1-methyl-1,2-ethanediyl)bis-, $\left(\mathrm{C}_{15} \mathrm{H}_{16}\right)$, retention time 19.30, compound is Benzene,1,1-(1,3-Propanediyl)bis- $\left(\mathrm{C}_{15} \mathrm{H}_{16}\right)$, retention time 21.61, compound is Naphthalene,1-Phenyl- $\left(\mathrm{C}_{16} \mathrm{H}_{12}\right)$ and finally at retention time 24.67 compound is 1,5-Hexadiyne $\left(\mathrm{C}_{6} \mathrm{H}_{6}\right)$ (see fig.6).

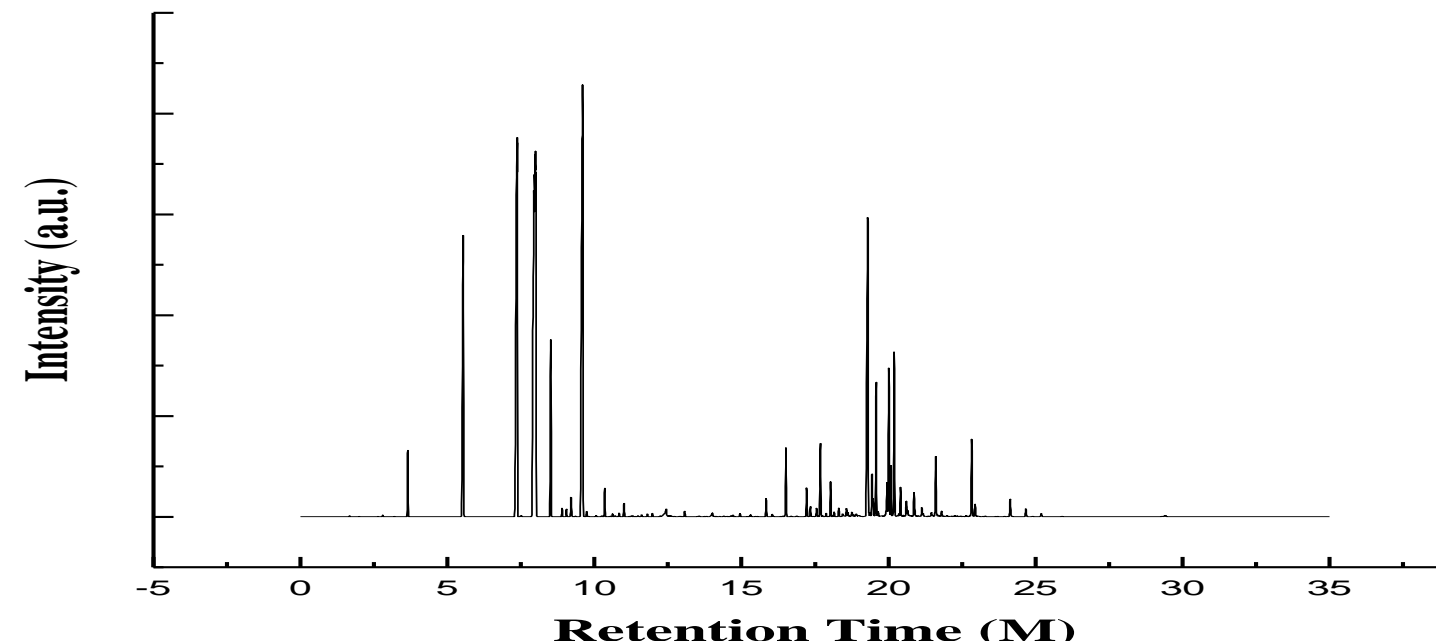

Figure 6: Gas Chromatography and Mass Spectrometer Chromatogram of PS to Fuel

In comparison study of GCMS analysis of four types of fuel such as HDPE-2 fuel, LDPE-4 fuel, PP-5 fuel and PS-6 fuel emerging that in different retention time various compounds are appeared. If analyses the carbon range of each individual fuel found that in HDPE-2 fuel carbon range is C3 to c28, LDPE-4 fuel carbon range is $C_{3}$ to $C_{28}$, PP- 5 carbon range is $C_{3}$ to $C_{25}$ and PS- 6 carbon range is $C_{6}$ to $C_{18}$. Comparative discussion among compound arrangement in each individual fuel such in HDPE-2 fuel obtained compounds are Propane to octacosane, in LDPE-4 fuel compound are Cyclopropane to Octacosane, in PP-5 fuel obtain compounds are CycloProppane to Dodecane, 1-cyclopentyl-4(3-cyclopentyl propyl) - and finally in PS-6 fuel initial compound 
is 1, 5-Hexadiyne $\left(\mathrm{C}_{6} \mathrm{H}_{6}\right)$ and final compound is compound is 1, 5-Hexadiyne $\left(\mathrm{C}_{6} \mathrm{H}_{6}\right)$. In different retention time various kinds of compounds noticed in each individual fuel.

In GCMS analysis at higher retention time bulky compound and lower retention time light compounds are derived. In PS-6, HDPE-2, LDPE-4 and PP-5 analysis we noticed that more aliphatic and aromatic hydrocarbon compounds arranged by their group and functional radical as well and each fuel appeared distinguishable hydrocarbon compound respectively.

\subsection{FT-IR (Fourier Transform Infra-red Spectroscopy) Analysis}

High Density Polyethylene (HDPE-2) Fuel was analyzed by FT-IR, following types of functional groups are appeared in belongs to wave number. According to spectrum band peak different number of wave number emerged and in versus of peak wave number several kind of functional radicals are obtained. In accordance with wave number compound are elaborated such as wave number $2956.38\left(\mathrm{~cm}^{-1}\right)$ compound is $\mathrm{C}_{-} \mathrm{CH}_{3}$, wave number $2853.19\left(\mathrm{~cm}^{-1}\right)$ compound is $\mathrm{CH}_{2}$, wave number $1641.69\left(\mathrm{~cm}^{-1}\right)$, compound is Non-Conjugated, wave number 1465.41, compound is $\mathrm{CH}_{3}$, wave number $991.76\left(\mathrm{~cm}^{-1}\right)$, compound is $-\mathrm{CH}=\mathrm{CH}_{2}$, wave number 965.02( $\left.\mathrm{cm}^{-1}\right)$, compound is $-\mathrm{CH}=\mathrm{CH}-\left(\right.$ Trans), wave number $909.08\left(\mathrm{~cm}^{-1}\right)$, compound is $-\mathrm{CH}=\mathrm{CH}_{2}$ and finally on wave number $721.39\left(\mathrm{~cm}^{-1}\right)$ and $667.88\left(\mathrm{~cm}^{-1}\right)$ found compound is $-\mathrm{CH}=\mathrm{CH}-(\mathrm{cis})$.

Noticeable that in some near about wave numbers is sited between in range and same compounds are derived.

HDPE 2 .sp / Spectrum.lst Euclidean Search Hit List: 0.969 K00939 L21468.DX 1-NONADECENE, 0.967 K00878 L14224.DX 1-HEXADECENE, 0.959 K01293 L66086.DX 1-OCTADECENE, 0.959 K01078 L66086.DX 1-OCTADECENE, 0.955 K00886 L14513.DX 1-ICOSENE, 0.953 K00913 L17800.DX 1HEPTADECENE, 0.952 DA1102 OCTADECENE-1 (LIQUID FILM), 0.951 K00989 L26271.DX 1PENTADECENE, 0.945 DA1101 HEXADECENE-1 (LIQUID FILM), 0.945 DA1100 TETRADECENE-1 (LIQUID FILM) (Fluka library transferred from 7000)

Low Density Polyethylene (LDPE-4) Fuel was also analyzed by FTIR (Fourier Transform Infra-red Spectroscopy), following types of functional groups are appeared in belongs to wave number. According to spectrum band peak different number of wave number emerged and in versus of peak wave number several kind of functional radicals are obtained. In accordance with wave number compound are elaborated such as wave number $2956.72\left(\mathrm{~cm}^{-1}\right)$ compound is $\mathrm{C}-\mathrm{CH}_{3}$, wave number $2922.13\left(\mathrm{~cm}^{-1}\right)$ compound is $\mathrm{C}-\mathrm{CH}_{3}$, wave number $2853.50\left(\mathrm{~cm}^{-1}\right)$, compound is $\mathrm{CH}_{2}$, wave number $1641.78\left(\mathrm{~cm}^{-1}\right)$, compound is Non-Conjugated ,wave number 1458.43, compound is $\mathrm{CH}_{3}$, wave number 1377.96, compound is $\mathrm{CH}_{3}$, wave number $964.96\left(\mathrm{~cm}^{-1}\right)$, compound is $-\mathrm{CH}=\mathrm{CH}$-(Trans), wave number $909.10\left(\mathrm{~cm}^{-1}\right)$, compound is $-\mathrm{CH}=\mathrm{CH}_{2}$, wave number $887.93\left(\mathrm{~cm}^{-1}\right)$, compound is $\mathrm{C}=\mathrm{CH}_{2}$ and finally on wave number $721.71\left(\mathrm{~cm}^{-1}\right)$ and $667.91\left(\mathrm{~cm}^{-1}\right)$ found compound is $\mathrm{CH}=\mathrm{CH}-(\mathrm{cis})$.

LDPE 4 .sp / Spectrum.lst Euclidean Search Hit List: 0.971 K00878 L14224.DX 1-HEXADECENE , 0.970 K00939 L21468.DX 1-NONADECENE, 0.963 K01293 L66086.DX 1-OCTADECENE, 0.963 K01078 L66086.DX 1-OCTADECENE, 0.955 K00989 L26271.DX 1-PENTADECENE, 0.954 K00886 L14513.DX 1ICOSENE, 0.953 K00825 L12200.DX 1-TRIDECENE, 0.951 K00913 L17800.DX 1-HEPTADECENE, 0.951 F74740 1-OCTADECENE 0.947 DA1100 TETRADECENE-1 (LIQUID FILM) (Fluka library transferred from 7000)

From FTIR (Fourier Transform Infra-red Spectroscopy) analysis of Polypropylene (PP-5) in according to wave number several types of functional groups are found. If we analyze the peak and wave number of spectrum appearing that in wave number $3074.99\left(\mathrm{~cm}^{-1}\right)$, the compound is $\mathrm{H}$ Bonded NH, chronologically wave number $2955.87\left(\mathrm{~cm}^{-1}\right), 2912.71\left(\mathrm{~cm}^{-1}\right)$ and $2871.87\left(\mathrm{~cm}^{-1}\right)$, derive compound is $\mathrm{C}_{-} \mathrm{CH}_{3}$. Subsequently wave number $1650.20\left(\mathrm{~cm}^{-1}\right)$, compound is amides, wave number $1465.95\left(\mathrm{~cm}^{-1}\right)$, compound is $\mathrm{CH}_{2}$, wave number $1377.07\left(\mathrm{~cm}^{-1}\right)$, compound is $\mathrm{CH}_{3}$, wave number $965.06\left(\mathrm{~cm}^{-1}\right)$, compound is $-\mathrm{CH}=\mathrm{CH}-($ Trans), wave number 887.02, compound is $\mathrm{C}=\mathrm{CH}_{2}$ and finally wave number $739.06\left(\mathrm{~cm}^{-1}\right)$, compound is $-\mathrm{CH}=\mathrm{CH}-(\mathrm{cis})$.

PP 5 .sp / Spectrum.lst Euclidean Search Hit List: 0.904 K00787 L10678.DX 2, 4-DIMETHYL-1-HEXENE, 0.898 K01163 L58486.DX 2, 6-DIMETHYL-1-HEPTENE, 0.895 K01158 L58451.DX 2, 4-DIMETHYL-1HEPTENE, 0.881 K00811 L11245.DX 2, 4-DIMETHYL-1-PENTENE, 0.867 K00784 L10670.DX 2METHYL-1-HEPTENE 0.857 K01166 L58489.DX 2, 5-DIMETHYL-1-HEXENE, 0.850 K00866 L13612.DX 2-METHYL-1-HEXENE， 0.843 K00794 L10687.DX 2, 3-DIMETHYL-1-HEXENE, 0.839 K01316 L67876.DX 2-METHYL-1-PENTENE, 0.820 K00529 L02241.DX 2-ETHYL-1-HEXENE (Fluka library transferred from 7000) 
From FTIR (Fourier Transform Infra-red Spectroscopy) analysis of Polypropylene (PS-6) in according to wave number several types of functional groups are found. If we analyze the peak and wave number of spectrum appearing that in wave number $3083.59\left(\mathrm{~cm}^{-1}\right)$, the compound is $=\mathrm{C}-\mathrm{H}$, chronologically wave number $3060.73\left(\mathrm{~cm}^{-1}\right), 2966.73\left(\mathrm{~cm}^{-1}\right)$ and $2874.03\left(\mathrm{~cm}^{-1}\right)$, derive compound is $=\mathrm{C}-\mathrm{H}$ and $\mathrm{C}-\mathrm{CH}_{3}$. Subsequently wave number $1802.56\left(\mathrm{~cm}^{-1}\right)$, compound is Non-Conjugated, wave number $1630.02\left(\mathrm{~cm}^{-1}\right)$, compound is Conjugated, wave number $1414.28\left(\mathrm{~cm}^{-1}\right)$, compound is $\mathrm{CH}_{2}$, wave number $1376.10\left(\mathrm{~cm}^{-1}\right)$, compound is $\mathrm{CH}_{3}$, wave number 1028.94 compound is Acetates, wave number is $990.91\left(\mathrm{~cm}^{-1}\right)$,compound is $-\mathrm{CH}=\mathrm{CH}_{2}$ and finally on wave number $729.65\left(\mathrm{~cm}^{-1}\right)$, compound is $-\mathrm{CH}=\mathrm{CH}-(\mathrm{cis})$.

PS 6 .sp / Spectrum.lst Euclidean Search Hit List: 0.749 K00748 L10290.DX STYRENE, 0.749 K00811 L10290.DX STYRENE, 0.749 K00419 L10290.DX STYRENE, 0.742 PT0523 STYRENE (10-15PPM TERTBUTYL CATECHOL) 0.742 PA0117 STYRENE, 0.671 F13280 BENZYL CHLORIDE, 0.663 K00462 L00638.DX 1,1-DIPHENYLETHYLENE, 0.643 K01369 L74757.DX 4-METHYL-2,4-DIPHENYL-1$\begin{array}{lllllll}\text { PENTENE } & 0.630 & \text { K01318 L67879.DX } & \text { CIS-STILBENE, } 0.613 & \text { K00351 K59427.DX 1,2- }\end{array}$ BIS(DIPHENYLMETHYLENE)CYCLOBUTANE (Fluka library transferred from 7000)

Comparative study of HDPE-2, LDPE-4, PP-5 \& PS-6 fuel emerging that in different band and wave number different functional groups and compound derived. In some cases wave number are matches with one wave to another wave number including compound identification is also found same compound or group. In HDPE-2, LDPE-4, PP-5 and PS-6 fuel common functional groups are $\mathrm{CH}_{3}, \mathrm{C}_{-} \mathrm{CH}_{3}, \mathrm{CH}_{2},-\mathrm{CH}=\mathrm{CH}$-(cis) and $\mathrm{CH}=\mathrm{CH}$-(trans). The spectrum feature of each individual fuel is uniquely identified. Although wave number and spectrum band very near in each other so that derived compound functional group mostly common in radical group. Noticeable that wave number of each individual fuel ascending to $700 \mathrm{~cm}^{-1}$ to $750 \mathrm{~cm}^{-1}$ and most probably compound is $-\mathrm{CH}=\mathrm{CH}$-(cis) and $-\mathrm{CH}=\mathrm{CH}$-(trans) groups. Besides common group available functional radical are also present in each fuel such as $\mathrm{C}-\mathrm{CH}_{3}, \mathrm{C}=\mathrm{CH}_{2},-\mathrm{CH}=\mathrm{CH}_{2},=\mathrm{C}-\mathrm{H}$ and so on.

\subsection{DSC (Differential Scanning Calorimeter) Analysis}

Differential Scanning Calorimeter(DSC)were also use to analysis purposes, Temperature ranges is $25^{\circ} \mathrm{C}$ to 400 ${ }^{\circ} \mathrm{C}$, Use gas Nitrogen is $\left(\mathrm{N}_{2}\right)-30$ psi, Input gas $20 \mathrm{ml} /$ minute, Ramping Rate $10^{\circ} \mathrm{C} /$ minute, Used Cooler: Intra Cooler Cooling Accessory, Pan Size:50 $\mu$ L,Used Sample: $40 \mu \mathrm{L}$, Experiment Run Time: 38 minute.

Each individual fuel was analyzed by DSC. From DSC analysis of HDPE-2 fuel, noticeable that onset temperature is $113.72^{\circ} \mathrm{C}$. At this temperature fuel starting to boiled up and could be stated that the boiling point of HDPE-2 fuel. In addition other factors results are given below: Peak $=115.37^{\circ} \mathrm{C}$, Peak Height $=30.5046 \mathrm{Mw}$, Area $=13005.1946 \mathrm{~mJ}$, Delta H $=13005.1946 \mathrm{~J} / \mathrm{g}$, Delta Hf $=13.0052 \mathrm{~kJ} / \mathrm{mol}$, Mol.Wt. $=1.000 \mathrm{~g} / \mathrm{mole}$ (fig.7)

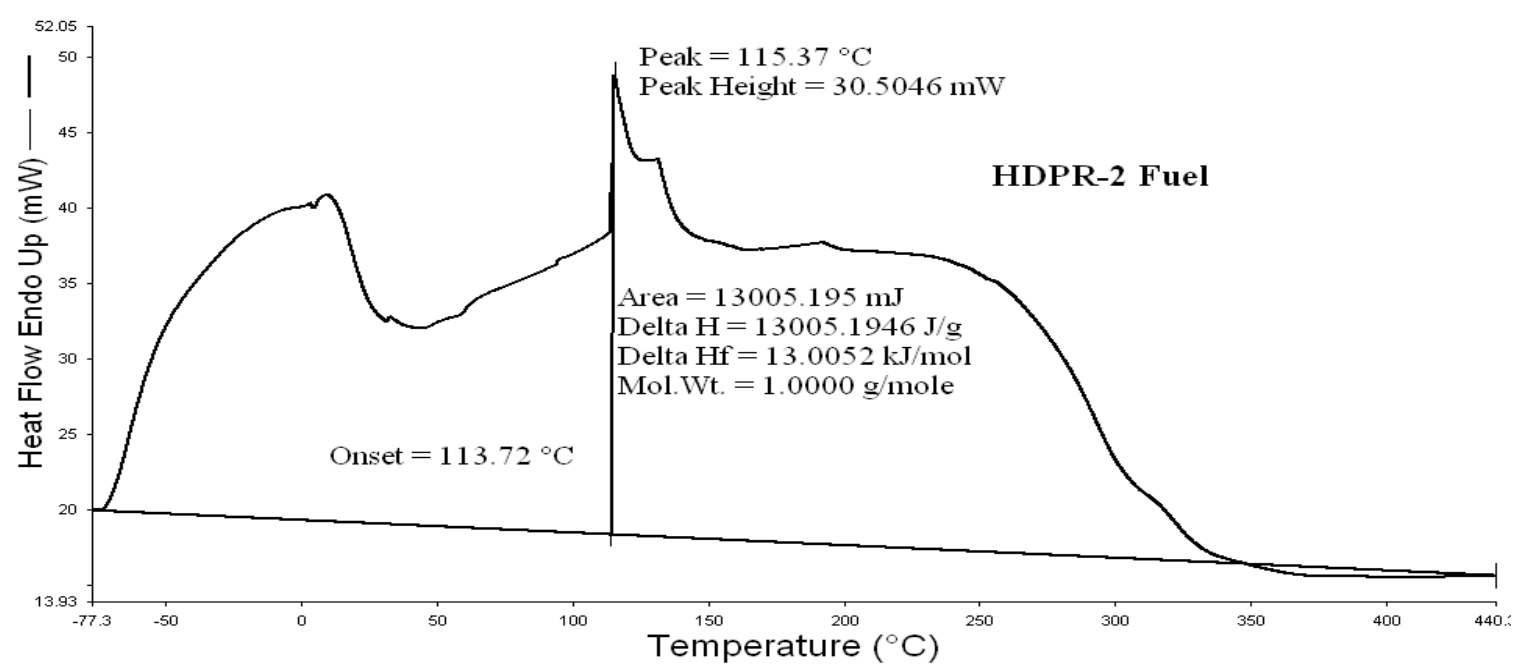

Figure 7: Differential Scanning Calorimeter (Jade- DSC) Graph of HDPE Waste Plastic to Fuel

From DSC analysis of LDPE-4 fuel are appearing that onset temperature is $76.57^{\circ} \mathrm{C}$. First able we can reached at decision that is the boiling point of LDPE-4 fuel. Subsequently other factors are discussed.

Obtain results are given below: Peak $=79.16{ }^{\circ} \mathrm{C}$, Peak Height $=12.6861 \mathrm{Mw}$, Area $=7648.620 \mathrm{~mJ}$, Delta H $=$ $7648.6199 \mathrm{~J} / \mathrm{g}$, Delta Hf $=7.6486 \mathrm{~kJ} / \mathrm{mol}$, Mol.Wt. $=1.000 \mathrm{~g} / \mathrm{mole}$ (see fig. 8 ). 


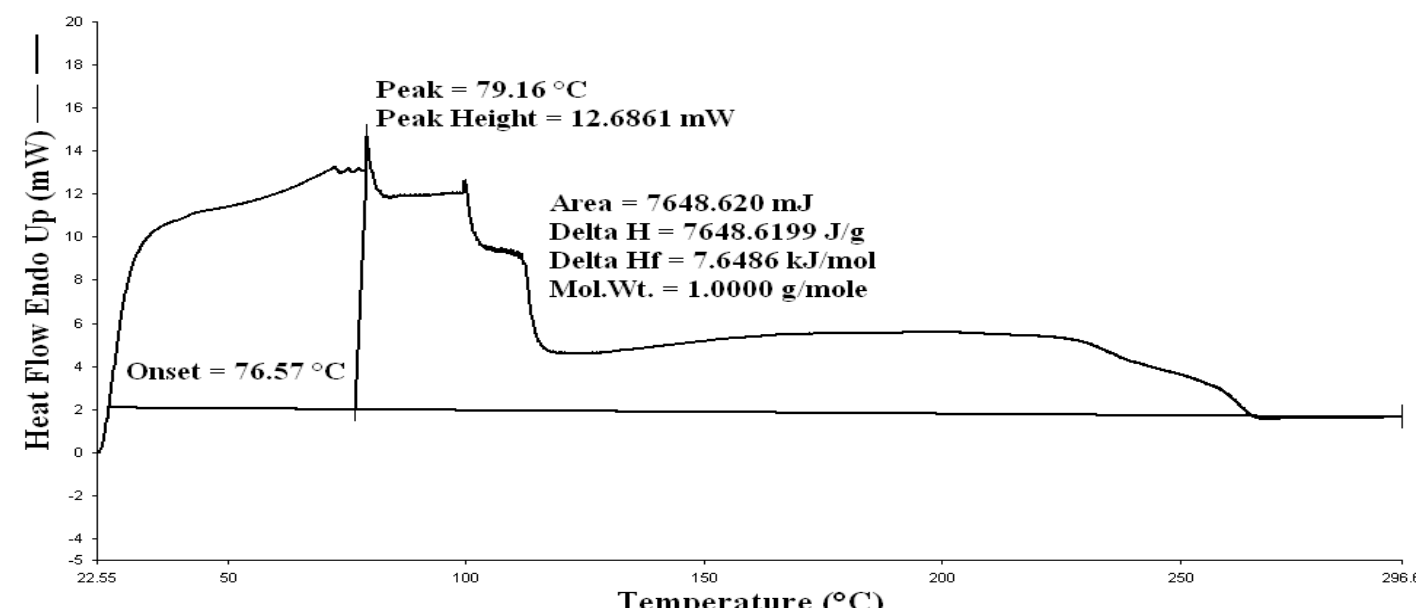

Figure 8: Differential Scanning Calorimeter (Jade- DSC) Graph of LDPE Waste Plastic to Fuel

From DSC analysis of PP-5 fuel emerge that onset temperature is $71.03^{\circ} \mathrm{C}$. Onset temperature is a temperature in which fuel boiled up. According to analysis result following types of items is found from analysis. Obtain results are given below: Peak $=178.84{ }^{\circ} \mathrm{C}$, Peak Height $=9.7160 \mathrm{Mw}$, Area $=6384.424 \mathrm{~mJ}$, Delta $\mathrm{H}=6384.4241$ $\mathrm{J} / \mathrm{g}$, Delta $\mathrm{Hf}=6.3844 \mathrm{~kJ} / \mathrm{mol}$, Mol.Wt. $=1.000 \mathrm{~g} / \mathrm{mole}($ see fig.9)

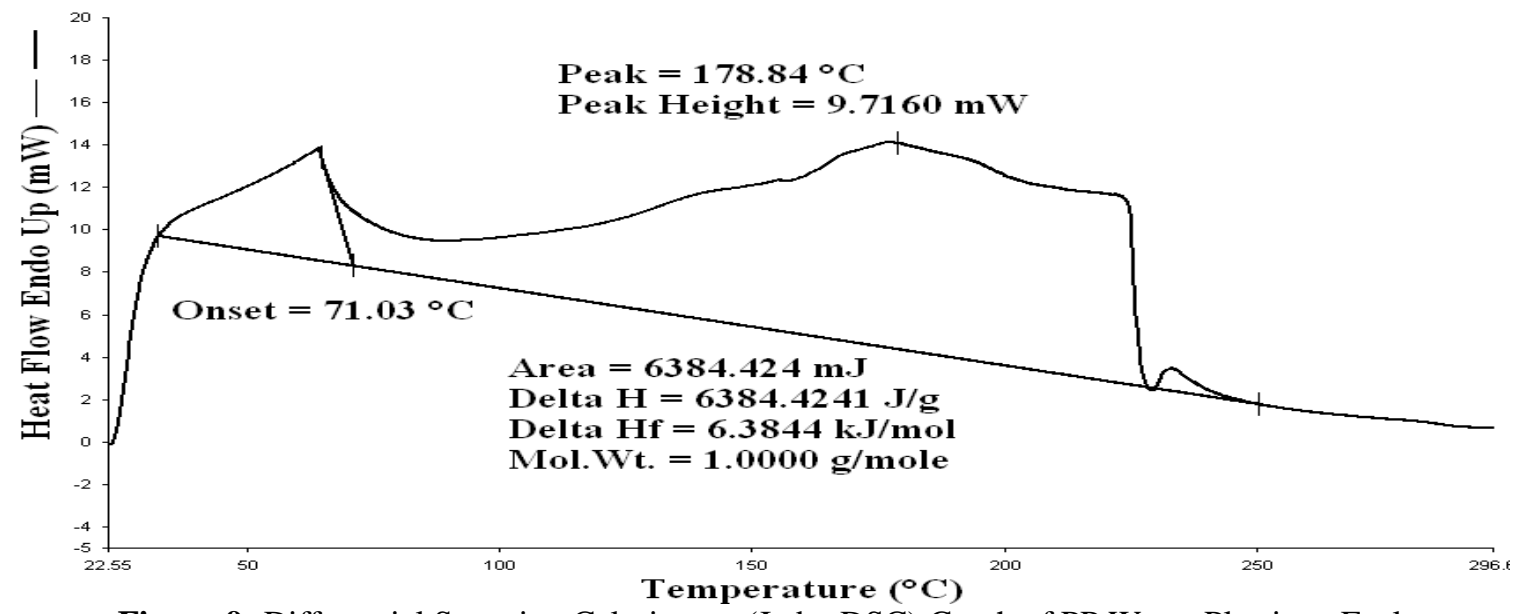

Figure 9: Differential Scanning Calorimeter (Jade- DSC) Graph of PP Waste Plastic to Fuel

From DSC analyses of PS-6 fuel found that onset temperature $140.19^{\circ} \mathrm{C}$. Besides other parameter are described in details correspondingly. Obtain results are given below: Peak $=156.76^{\circ} \mathrm{C}$, Peak Height $=77.9130 \mathrm{Mw}$, Area $=$ $13454.767 \mathrm{~mJ}$, Delta H = $13454.7669 \mathrm{~J} / \mathrm{g}$, Delta Hf $=13.4548 \mathrm{~kJ} / \mathrm{mol}$, Mol.Wt. $=1.000 \mathrm{~g} / \mathrm{mole}$ (see fig.10).

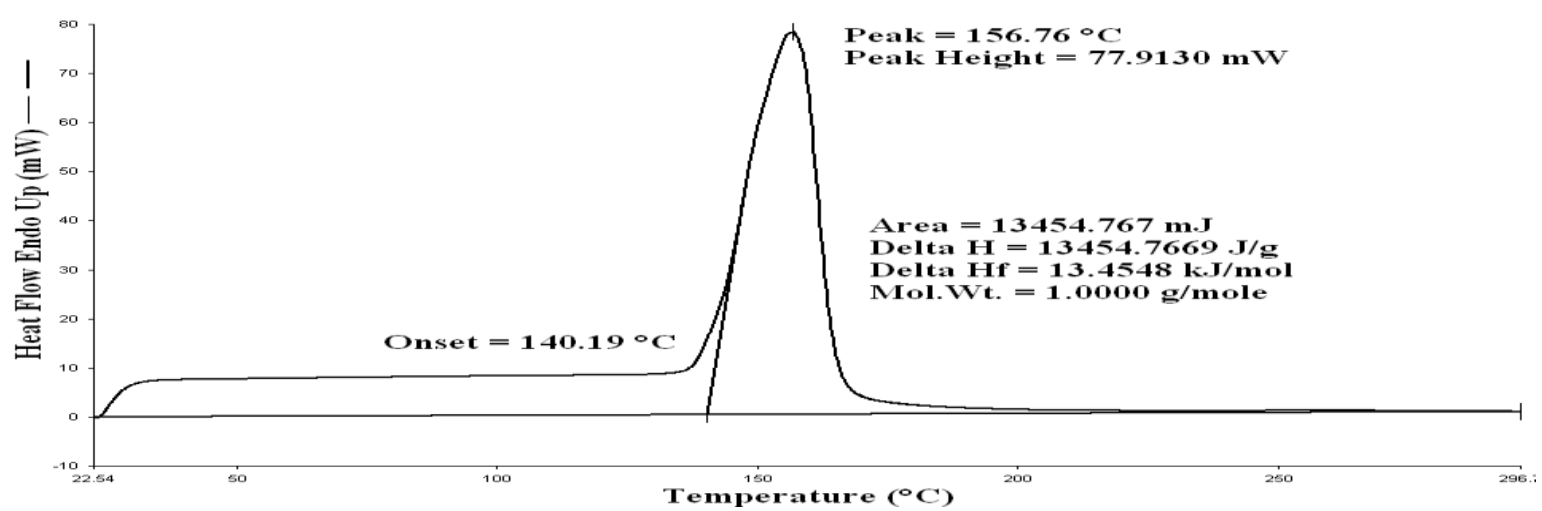

Figure10: Differential Scanning Calorimeter (Jade- DSC) Graph of PS Waste Plastic to Fuel

Basically by DSC analysis identify the boiling point, melting point and freezing point of target substances. 
Four types of individual fuel such as HDPE-2, LDPE-4, PP-5 and PS-6 were analyzed in DSC. In DSC analysis came out that of HDPE-2 fuel onset temperature is $113.72^{\circ} \mathrm{C}$, LDPE-4 fuel onset temperature is

$76.57^{\circ} \mathrm{C}$, PP-5 fuel onset temperature is $71.03{ }^{\circ} \mathrm{C}$ and PS-6 fuel onset temperature is $140.19^{\circ} \mathrm{C}$. Onset temperature represents the boiling points of individual each fuel. In DSC analysis appeared that different types of parameter emerged and each fuel analysis curve distinguishable in Onset, Peak area, peak Height, area and enthalpy. During analysis execution identical equipment systematical procedure followed and gas purge (Nitrogen, $30 \mathrm{psi}$ ) used for each individual fuel as well as starting temperature was room temperature that is 25 ${ }^{\circ} \mathrm{C}$.

\section{ASTM Test Results}

Table 4: Waste plastic individual fuel Btu and Mega Joule/gallon value

\begin{tabular}{|c|c|c|c|}
\hline $\begin{array}{c}\text { Name of Waste } \\
\text { Plastic to Fuel }\end{array}$ & ASTM Test Method & $\begin{array}{c}\text { Gross Heat of } \\
\text { Combustion Btu/Gal }\end{array}$ & Mega Joule/Gal \\
\hline HDPE-2 & D240 & 123,845 & 130.66 \\
\hline LDPE-4 & D240 & 126,247 & 133.19 \\
\hline PP-5 & D240 & 125,307 & 132.20 \\
\hline PS-6 & D240 & 134,202 & 141.59 \\
\hline
\end{tabular}

Table 5: Individual Fuels API Gravity and Sulfur Content

\begin{tabular}{|c|c|c|c|c|c|}
\hline ASTM Method & Test Name & HDPE-2 Fuel & LDPE-4 Fuel & PP-5 Fuel & PS-6 Fuel \\
\hline D4052 & $\begin{array}{c}\text { API Gravity } @ \\
60^{\circ} \mathrm{F}\end{array}$ & $53.70^{\circ} \mathrm{API}$ & $52.50^{\circ} \mathrm{API}$ & $56.40^{\circ} \mathrm{API}$ & $25.10^{\circ} \mathrm{API}$ \\
\hline D5453 & Sulfur & $3.05 \mathrm{ppm}$ & $2.10 \mathrm{ppm}$ & $<1.0 \mathrm{ppm}$ & $4.50 \mathrm{ppm}$ \\
\hline
\end{tabular}

Table 4 and table 5 are showed some ASTM test results of NSR individual waste plastic to fuel.

Table 6: Solid Black Residue Analysis Result by ICP

\begin{tabular}{|c|c|c|}
\hline ASTM Test Method & Metals Name & Result/ppm \\
\hline \multirow[t]{24}{*}{ ASTM D1976 } & Silver & 18.18 \\
\hline & Aluminum & 5674.63 \\
\hline & Arsenic & 21.1 \\
\hline & Boron & 14.2 \\
\hline & Barium & 1592.2 \\
\hline & Beryllium & $<1.0$ \\
\hline & Calcium & 23409.9 \\
\hline & Cadmium & 1.1 \\
\hline & Chromium & 22.5 \\
\hline & Copper & 126.3 \\
\hline & Iron & 2035.2 \\
\hline & Potassium & 5539 \\
\hline & Lithium & $<1.0$ \\
\hline & Magnesium & 421.9 \\
\hline & Manganese & 14.5 \\
\hline & So dium & 18491.6 \\
\hline & Nickel & 139.4 \\
\hline & Lead & 54.5 \\
\hline & Antimony & $<1.0$ \\
\hline & Selenium & $<1.0$ \\
\hline & Silicon & 421.8 \\
\hline & Tin & 51.5 \\
\hline & Titanium & 4835.9 \\
\hline & Vanadium & $<1.0$ \\
\hline & Zinc & 1176.4 \\
\hline
\end{tabular}

Residue analysis result obtained by $3^{\text {rd }}$ party ASTM test (Texas oil tech laboratory Inc.) is showing (Table 6) metal contain ppm levels are high. Because when plastic are made that time for plastic good performance are adding different types of additives up to $3 \%$. Those additives we are getting as a black carbon solid residue after fuel production process. This element is not affecting NSR fuel because of our NSR fuel conversion technology optimum temperature is only up to $420^{\circ} \mathrm{C}$. This residue element boiling point and melting point temperature are more than $400{ }^{\circ} \mathrm{C}$ that's why when NSR technology converting waste plastic to fuel is not coming out with fuel. 
If some element is come out with fuel that element ppm level less than $1 \mathrm{ppm}$ which is very negligible (Table 7). Residue has also Btu value 5,742/ lb (ASTM D 240) and it bulk density $0.93 \mathrm{~g} / \mathrm{cm} 3$ (ASTM D1480) and elemental analysis result are showing $\mathrm{C}=28.78 \%, \mathrm{H}=0.38 \%$ and $\mathrm{N}=<0.30 \%$.

Table 7: Metal Content present into NSR Fuel by ICP

\begin{tabular}{|c|c|c|}
\hline ASTM Test Method & Compound/Element Name & Result \\
\hline ASTM D240 & Vanadium & $<1.00 \mathrm{mg}$ \\
\hline ASTM D2708 & Nickel & $<1.00 \mathrm{ppm}$ \\
\hline ASTM D2708 & Iron & $2.70 \mathrm{ppm}$ \\
\hline ASTM D2708 MOD & Calcium & $<1.00 \mathrm{ppm}$ \\
\hline ASTM D2708-MOD & Copper & $<1.00 \mathrm{ppm}$ \\
\hline ASTM D2708_MOD & Sodium & $<1.00 \mathrm{ppm}$ \\
\hline
\end{tabular}

\section{Conclusion}

Each of individual experiment investigated and monitored properly. Experiment run time temperature contour maintained by variac meter to protect over heating and overlapping of glass reactor inside slurry as well as restrain the super crack of boiling flask. Initial state of the experiment temperature rose to higher temperature such as $400{ }^{\circ} \mathrm{C}$ to melt the solid plastics. When initial waste plastics sample melted and its taken about 30 minute to produce vapor to first drop of fuel production. At that state drop of fuel production rate spontaneously increasing and to bring the stable state of fuel production temperature were decreased to $315^{\circ} \mathrm{C}$. By closely studied on several experiment in NSR laboratory, found that optimum and expected production captured in 300$315^{\circ} \mathrm{C}$. End of the experiment to enhance the production yield temperature rose to $420{ }^{\circ} \mathrm{C}$ to reach the maximum yield of production margin. At the higher state of temperature every experiment monitored and controlled very sincerely to overcome any serious incidence and occurrences. Once sample finished experiment shutdown and to allow cool down the experiment for 15 minutes. Subsequently liquid product (fuel) collected and analyzed the properties and densities. In comparative studies of density found that HDPE-2 fuel density is $0.782 \mathrm{~g} / \mathrm{ml}$, LDPE-4 fuel density is $0.771 \mathrm{~g} / \mathrm{ml}$, PP-5 fuel density is $0.759 \mathrm{~g} / \mathrm{ml}$ and PS-6 fuel density is 0.916 $\mathrm{g} / \mathrm{ml}$. Similarly in analytical studied found that they have significant variation in components and elements. In FTIR and GCMS analysis of each individual fuel found that most of the functional group and compound are not unique in each other, varied to different types of compounds. In GCMS Analytical study found that in different fuel has a different type of aliphatic and aromatic compound including six member rings and five member heterocyclic rings compound respectively. In comparative study of chemical structure of HDPE-2 and LDPE-4 similar $-\mathrm{CH}_{2}-\mathrm{CH}_{3}$ - group are appeared in their polymer chain, where as PP-5 and PS- 6 both structure contains aromatic benzene compound including methylene group but PP-5 contain methyl $-\mathrm{CH}_{3}$ - group that group not found in PS-6. PS-6 contains plenty of methylene, benzene monomer in the long chain hydrocarbon. Detail analytical information is discussed in result and discussion section of the paper.

\section{Acknowledgement}

The authors acknowledge the support (Financial) of Dr. Karin Kaufman, the founder and sole owner of Natural State Research, Inc (NSR). The authors also acknowledge the valuable contributions NSR laboratory team members during the preparation of this manuscript.

\section{References}

[1] Achyut K.Panda, R.K Singh, D.K Mishara: Thermolysis of waste plastics to fuel, Department of Chemical Engineering. National Institute of Technology, Rourkela, Orissa, India. Renewable and Sustainable Energy Reviews 14 (2010)233-243,

[2] Abstract published in Advance ACS Abstracts, March 15, 1997.Reisch, Marc S.Chem.Eng.News 1995, May 22, 30

[3] Friedman S.PETC Review, Pittsburg Energy Technology Center U.S. Department of Energy, Vol. 12, winter; PETC: Pittsburg, PA, 1996; p 14.

[4] D.S. Achilias, European Polymer Journal 43 (6) (2007) 2564-2575.

[5] United States Environment Protection Agency (USEPA), Municipal Solid Waste Generation, Recycling and Disposal in the United States: Facts and Figures for 2006, available on line at http://www.epa.gov/garbage/plastic.htm

[6] Aguado J, Serrano DP, Escola MJ. Fuels from waste plastics by thermal and catalytic processes: a review. Ind Eng Chem Res 2008; 47(21):7982-92.

[7] Stelmachowski M. Thermo-catalytic degradation of waste polymers (Termokatalityczna degradacja polimerów) Monograph (in polish), Polish Academy of Sciences (PAN), The Committee of Environmental Protection, Lodz; 2003. ISBN 83-86492-19-8.0

[8] Siddique R, Khatib J, Kaur I. Use of recycled plastic in concrete: a review. Waste Manage 2008;28:1835-52.

[9] Ikusei Nakamura *, Kaoru Fujimoto, Development of new disposable catalyst for waste plastics treatment for high quality transportation fuel, Catalysis Today 27 (1996) 175-179

[10] G. dela Puente, C. Klocker, U. Sedran*, Conversion of waste plastics into fuels Recycling Polyethylene in FCC, Applied Catalysis B: Environmental 36 (2002) 279-285 
[11] Nnamso S. Akpanudoh, Karishma Gobin, George Manos*, Catalytic degradation of plastic waste to liquid fuel over commercial cracking catalysts Effect of polymer to catalyst ratio/acidity content, Journal of Molecular Catalysis A: Chemical 235 (2005) 6773

[12] A.G. Buekens *, H. Huang, Catalytic plastics cracking for recovery of gasoline-range hydrocarbons from municipal plastic wastes, Resources, Conservation and Recycling 23 (1998) 163-181

[13] N. Lingaiah, Md. A. Uddin, A. Muto, T. Imai, Y. Sakata*, Removal of organic chlorine compounds by catalytic dehydrochlorination for the refinement of municipal waste plastic derived oil, Fuel 80 (2001) 1901-1905

[14] Wei-Chiang Huang, Mao-Suan Huang, Chiung-Fang Huang, Chien-Chung Chen ${ }^{*}$ Keng-Liang Ou**, Thermochemical conversion of polymer wastes into hydrocarbon fuels over various fluidizing cracking catalysts, Fuel 89 (2010) 2305-2316

[15] M. Rasul Jan *, Jasmin Shah, Hussain Gulab, Catalytic degradation of waste high-density Polyethylene into fuel products using $\mathrm{BaCO}_{3}$ as a catalyst, Fuel Processing Technology, FUPROC-02821; No of Pages 10, (2010)

[16] Jerzy Walendziewski_, Mieczysław Steininger, Thermal and catalytic conversion of waste polyolefines, Catalysis Today 65 (2001) $323-330$

[17] Selhan Karagoz, Tamer Karayildirim, Suat Ucar, Mithat Yuksel, Jale Yanik*, Liquefaction of municipal waste plastics in VGO over acidic and non-acidic catalysts, Fuel 82 (2003) 415-423

[18] Junya Nishino *, Masaaki Itoh, Hironobu Fujiyoshi , Yoshio Uemichi, Catalytic degradation of plastic waste into petrochemicals using Ga-ZSM- 5, Fuel 87 (2008) 3681-3686

[19] Weibing Ding, Jing Liang, Larry L. Anderson*, Thermal and catalytic degradation of high density polyethylene and commingled post-consumer plastic waste, Fuel Processing Technology 51 (1997) 47-62

[20] W.B. Ding, W. Tuntawiroon, J. Liang, L.L. Anderson *, Depolymerization of waste plastics with coal over metal-loaded silicaalumina catalysts, Fuel Processing Technology 49 (1996) 49-63

[21] N. Miskolczi ${ }^{*}$, L. Bartha, G. Deak, B. Jover, Thermal degradation of municipal plastic waste for production of fuel-like hydrocarbons, Polymer Degradation and Stability 86 (2004) 357-366.

[22] Jerzy Walendziewski, Continuous flow cracking of waste plastics, Fuel Processing Technology 86 (2005) 1265- 1278

[23] Anthony Warren, Mahmoud El-Halwagi *, An economic study for the co-generation of liquid fuel and hydrogen from coal and municipal solid waste, Fuel Processing Technology 49 (1996) 157-166

[24] Guang-Hua Zhang*, Jun-Feng Zhu, A. Okuwaki, Prospect and current status of recycling waste plastics and technology for converting them into oil in China, Resources, Conservation and Recycling 50 (2007) 231-239

[25] Miguel Miranda*, Filomena Pinto, I. Gulyurtlu, I. Cabrita, C.A. Nogueira, Arlindo Matos, Response surface methodology optimization applied to rubber tyre and plastic wastes thermal conversion, Fuel 89 (2010) 2217-2229

[26] M. Stelmachowski *, Thermal conversion of waste polyolefins to the mixture of hydrocarbons in the reactor with molten metal bed, Energy Conversion and Management 51 (2010) 2016-2024.

[27] Li Wang*, Peng Chen, Development of first-stage co-liquefaction of Chinese coal with waste plastics, Chemical Engineering and Processing 43 (2004) 145-148.

[28] N. Miskolczi *, L. Bartha, J. Borsz'eki , P. Halmos, Determination of sulfur content of diesel fuels and diesel fuel-like fractions of waste polymer cracking, Talanta 69 (2006) 776-780.

[29] Prakash K. Ramdoss and Arthur R. Tarrer*, High-temperature liquefaction of waste plastics, PII: SOO16-2361(97) 00193-2, Fuel Vol. 77, No. 4, pp. 293-299, (1998) Elsevier Science Ltd.

[30] Zhen Feng, Jianmin Zhao, Jeff Rockwell, Den Bailey, Gerald Huffman *, Direct liquefaction of waste plastics and coliquefaction of coal - plastic mixtures, Fuel Processing Technology 49 (1996) 17- 30

[31] K. Gimouhopoulos*, D. Doulia, A. Vlyssides, D. Georgiou, Organic solvent effects on waste plastics-lignite Coliquefaction, Resources, Conservation and Recycling 23 (1998) 47-56.

[32] Andras Angyal *, Norbert Miskolczi, Laszlo Bartha, Petrochemical feedstock by thermal cracking of plastic waste, J. Anal. Appl. Pyrolysis 79 (2007) 409-414.

[33] Mohammad Nahid Siddiqui*, Conversion of hazardous plastic wastes into useful chemical products, Journal of Hazardous Materials 167 (2009) 728-735.

[34] Elizabeth A. Williams *, Paul T. Williams, Analysis of products derived from the fast pyrolysis of plastic waste, Journal of Analytical and Applied Pyrolysis 40-41 (1997) 347-363.

[35] N. Kiran *, E. Ekinci, C.E. Snape, Recyling of plastic wastes via pyrolysis, Resources, Conservation and Recycling 29 (2000) $273-283$

[36] Filomena Pinto *, Paula Costa, I. Gulyurtlu, I. Cabrita, Pyrolysis of plastic wastes 2. Effect of catalyst on product yield, Journal of Analytical and Applied Pyrolysis 51 (1999) 57-71

[37] Young-Hwa Seo*, Dae-Hyun Shin Determination of paraffin and aromatic hydrocarbon type chemicals in liquid distillates produced from the pyrolysis process of waste plastics by isotope- dilution mass spectrometry, Fuel 81 (2002) 2103-2112

[38] A. Lopez *, I. de Marco, B.M. Caballero, M.F.Laresgoiti, A. Adrados, Pyrolysis of municipal plastic wastes: Influence of raw material composition, Waste Management 30 (2010) 620-627 